14 - ORIGINAL ARTICLE

EXPERIMENTAL ORTHOPAEDIC SURGERY

\title{
Changes in morphology of long bone marrow tissue of rats submitted to cryotherapy with liquid nitrogen ${ }^{1}$
}

\author{
Alterações na morfologia do tecido medular de ossos longos de ratos submetido à crioterapia \\ com nitrogênio líquido
}

\section{Fábio Wildson Gurgel Costa ${ }^{\mathrm{I}}$, Rosana Maria Andrade Pessoa ${ }^{\mathrm{II}}$, Carlos Bruno Pinheiro Nogueira" ${ }^{\mathrm{II}}$, Karuza Maria Alves Pereira ${ }^{\mathrm{III}}$, Gerly Anne de Castro Brito ${ }^{\mathrm{IV}}$, Eduardo Costa Studart Soares ${ }^{\mathrm{V}}$}

${ }^{\mathrm{I}} \mathrm{MSc}$, Assistant Professor, Division of Stomatology, UFC Sobral Campus, Fortaleza-CE, Brazil. Responsible for conception, design, intellectual and scientific content of the study. Acquisition and interpretation of data, surgical procedures, manuscript writing.

IIDDS, Postgraduate student, Division of Oral Surgery, UFC, Fortaleza-CE, Brazil. Responsible for conception, design, intellectual and scientific content of the study. Acquisition and interpretation of data, surgical procedures.

IIIPhD, Associate Professor, Division of Oral Pathology, UFC Sobral Campus, Fortaleza-CE, Brazil. Acquisition and interpretation of data, macroscopic and histopathological examinations, critical revision.

${ }^{\mathrm{IV}} \mathrm{PhD}$, Full Professor, Division of Morphology, UFC, Fortaleza-CE, Brazil. Acquisition and interpretation of data, macroscopic and histopathological examinations, critical revision.

${ }^{\mathrm{v}} \mathrm{PhD}$, Associate Professor, Division of Oral Surgery, UFC, Fortaleza-CE, Brazil. Conception, design, intellectual and scientific content of the study, acquisition and interpretation of data, surgical procedures, manuscript writing, critical revision.

\begin{abstract}
PURPOSE: To study the main effects of local use of liquid nitrogen on bone marrow tissue in rats.

METHODS: The femoral diaphyses of 42 Wistar rats were exposed to three local and sequential applications of liquid nitrogen for one or two minutes, intercalated with periods of five minutes of passive thawing. The animals were sacrificed after one, two, four and 12 weeks and the specimens obtained were analyzed histomorphologically.

RESULTS: In the second experimental week of one-minute protocol, histological degree of inflammation obtained a mean score of one (mild), ranging from 0 (absent or scarce) and two (moderate) (Kruskal-Wallis test $\mathrm{p}=0.01$ ). In the second experimental week of twominute protocol, degree of inflammation to the medullar tissue obtained an average score of two (Kruskal-Wallis test $\mathrm{p}=0.01$ ).

CONCLUSION: The degree of inflammation of the bone marrow tissue was higher in protocol of three applications of two minutes compared to protocol of three applications of one minute.
\end{abstract}

Key words: Surgery, Oral. Nitrogen. Femur. Rats.

\section{RESUMO}

OBJETIVO: Investigar os principais efeitos do uso local de nitrogênio líquido sobre o tecido medular ósseo em ratos.

MÉTODOS: As diáfises femorais de 42 ratos Wistar foram expostas a três aplicações sequenciais locais de nitrogênio líquido por um ou dois minutos, intercaladas por períodos de cinco minutos de degelo espontâneo. Os animais foram sacrificados após uma, duas, quatro e 12 semanas e os espécimes obtidos foram analisados histomorfologicamente.

RESULTADOS: Na segunda semana experimental do protocolo de um minuto, o grau histológico de inflamação obteve um escore médio de um (leve) variando entre 0 (ausente ou escarço) a dois (moderado) (Teste de Kruskal-Wallis p=0.01). Na segunda semana experimental do protocolo de dois minutos, o grau histológico de inflamação do tecido medular obteve um escore máximo de dois (moderado) (Teste de Kruskal-Wallis p=0.01). CONCLUSÃO: O grau de inflamação do tecido medular ósseo foi maior no protocolo de três aplicações de dois minutos comparado ao protocolo de três aplicações de um minuto.

Descritores: Cirurgia Bucal. Nitrogênio. Fêmur. Ratos. 


\section{Introduction}

Cryosurgery is a method that uses low temperatures as a form of therapy providing several advantages in the treatment of locally aggressive lesions, mainly by non-complexity manner of implementation of the cryosurgical method, and the fact of preserving a non-pathological remaining bone, which can be devitalized without the need of surgical resection, besides serving as a recipient site for bone grafts ${ }^{1}$. Furthermore, it is described in the literature that this treatment compared to radical surgical techniques, allows a greater chance of preservation of vital structures, particularly the inferior alveolar nerve ${ }^{2}$.

The basic technique of surgical cryotherapy requires rapid cooling, followed by a slow thaw period, as well as repeating the process to maximize tissue destruction ${ }^{3}$. The two main recognized methods are a closed system, using probes, and an open system, which may be either spray or through the aid of cotton swabs ${ }^{4}$. The techniques employing liquid nitrogen through the closed system are due to direct contact between the probe tip and the target tissue offering a greater temperature control and greater penetration of freezing 5 .

Was recently published a study that described the main morphological findings of cryosurgery on cortical bone in a rat experimental model ${ }^{6}$. Given the importance of bone marrow tissue as a scaffold of support for the cortical tissue, as well as lack of standardized studies in this line of research, the aim of this study was to describe the main effects of local use of liquid nitrogen in an experimental model of rat femurs

\section{Methods}

The research protocol was submitted to the Ethics Committee in Animal Research at Federal University of Ceara, having been approved and licensed under the protocol $06 / 09$ on 11/08/2006.

The study was an experimental longitudinal, in vivo, of analytical approach, with independent samples and animals were randomly divided between the groups. Were chosen by simple random selection, 45 Wistar rats, clinically healthy, young adults, males, with weights ranging from 390 - 460g were kept in a animal colony under stable environmental conditions. The animals were randomly divided into two experimental groups and one control group, according to the standard application of liquid nitrogen or absence of. Was standardized as a group, the one where there were three cryogen applications for a minute, and second group where was applied three times, followed by two minutes each, using liquid nitrogen.

Each group was subjected to the experiment on a specific day. The animals were weighed and then was administered intraperitoneally tribromo-ethane $2.5 \%(0.1 \mathrm{ml} / 100 \mathrm{~g}$ body mass). After skin incision on femoral region was held detachment of adherent tissue, until locating the coxal-femoral joint, then joint ligaments were disconnected and being positioned $3 \mathrm{~mm}$ below the articular surface (craniocaudal direction) a spherical stainless steel surgical drill $\mathrm{n} \square 02$, long shaft, which was driven by an surgical electric motor in conjunction with copious saline $0.9 \%$ irrigation. Then it was standardized for all animals, the site to contact of the tip of the cryostat, which was $1 \mathrm{~cm}$ (cranial-caudal) of the surgical defect previously manufactured to $0.2 \mathrm{~mm}$ in depth. Subsequently, it has emerged the contact surface of the catheter tip closed the cryostat, and has been the application of liquid nitrogen on site according to previously defined groups.

The samples were stored in plastic Falcon tubes and fixed in $10 \%$ formaldehyde for 48 hours, decalcified in 5\% nitric acid for seven days buffered with sodium sulfate $5 \%$ irrigation for 24 hours and subsequently processed for microscopic analysis, with the dye technique using hematoxylin-eosin. Was conducted a descriptive analysis of the observed morphological changes compared with the control group, being collected in a qualitative way categorized as presence or absence to lose connective tissue, adipocytes, and intercellular edema congested vessels secondary bone tissue (osteoid) and bone tissue (mineralized). For the histological degree of inflammation, in addition, was created a ordinal variable with values to zero to three, with $0=$ absent or scarce (up to $5 \%$ of the sample), one $=$ mild (above $5 \%$ irrigation but less than $25 \%$ ), two $=$ moderate $(25 \%$ irrigation above and below $75 \%)$ and three $=$ intense severe $(>75 \%)$, being characterized by the intensity of the permeation of medullary tissue by lymphocytes, neutrophils plasma cells and macrophages.

\section{Results}

\section{Control group}

The animals not subjected to any experimental protocol, either the one minute or two minutes, were categorized as control group, resulting in four animals (for each week of sacrifice). The medullary tissue presented a normal appearance characterized by numerous red blood cells, adipocytes, and myeloid progenitor cells and lymphoid lineage. Viewing also internally osteoblasts lining marrow cavity (Figure 1). 


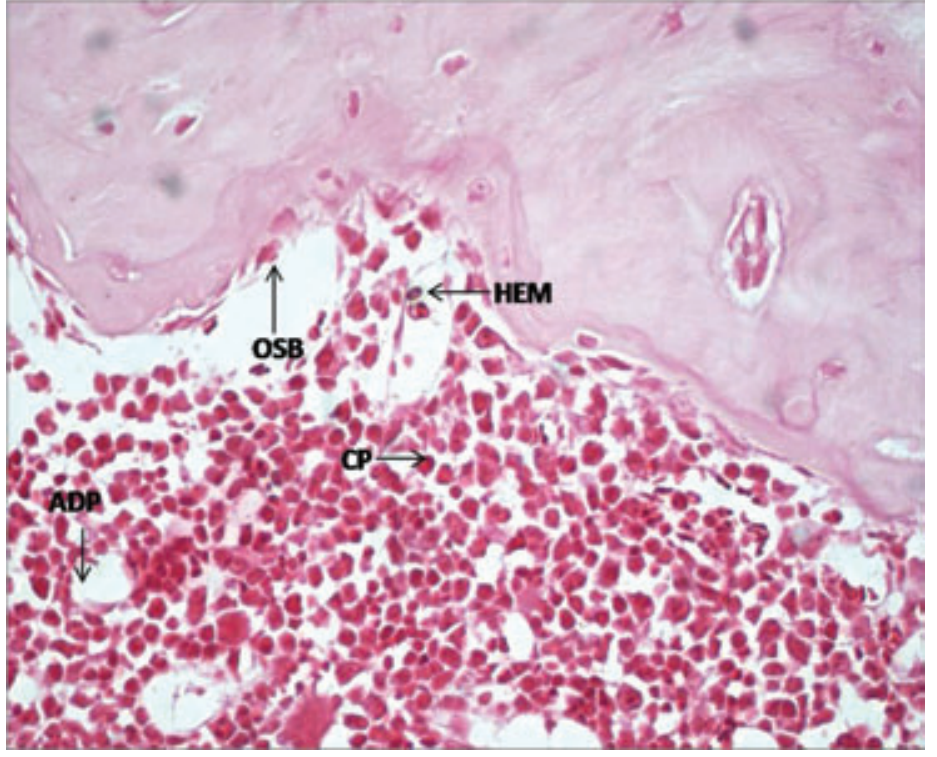

FIGURE 1 - Photomicrography of medullary tissue in control group (HE, $\mathrm{x} 400)$. Red blood cells (HEM) and extravasated progenitor cells $(\mathbf{C P})$ in bone marrow stroma were observed.

\section{One-minute experimental group}

In the first week, the medullary tissue showed to be intact, getting as histological grade of inflammation an average score of 0 (absent or scarce) in all samples representative of this group. Was observed a tissue without inflammation, and adipocyte progenitor cells scattered among the red blood cells and bone marrow stroma.

In the second experimental week were observed numerous adipocytes and with disproportionate sizes (Figure 2). The histological degree of inflammation to this group obtained a mean score of one (mild), ranging from 0 (absent or scarce) and two (moderate).

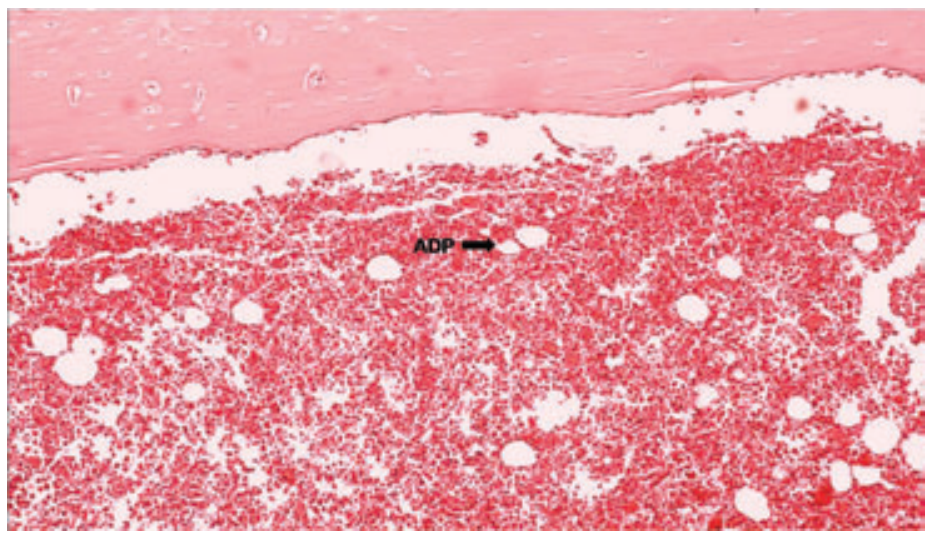

FIGURE 2 - Representative photomicrography of medullary tissue in one-minute protocol / two weeks (HE, x100). Presence of several adipocytes increased in size.

In the fourth week of observation the medullary tissue, presented to be altered, with large formation of adipocytes increased volume. There was also the material presence of osteoid (new bone) marrow dispersed in the matrix. The histological degree of inflammation to this group obtained a mean score of one (mild), ranging from 0 (absent or scarce) and one (mild).

At 12 weeks, the tissue presented to be altered, with the same pattern described in the previous group, being composed mainly of adipocytes of larger proportions, and extravasated red blood cells and other hematopoietic cells (Figure 3). The histological degree of inflammation to this group obtained a mean score of one (mild) with no variation. Table 1 shows the degree of medullar histological inflammation in the one-minute protocol.

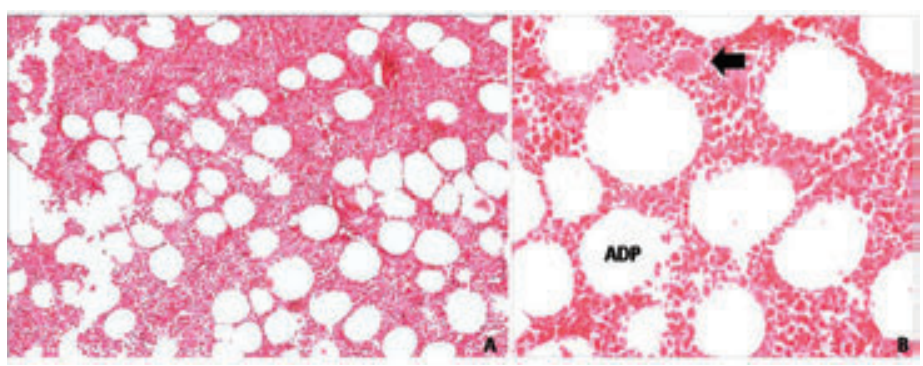

FIGURE 3 - Photomicrography of medullary tissue in one-minute protocol / 12 weeks. A) Matrix composed of several large adipocytes (HE, $\mathrm{x} 100)$; B) Higher magnification where are shown hematopoietic cells and multinucleated cells (arrow) (HE, x200).

TABLE 1 - Degree of medullar histological inflammation in the 1-minute protocol.

\begin{tabular}{cccccccccc}
\hline Week & N & Min. & Q1 & Mean & Q3 & Max. & $\begin{array}{r}\text { Mean } \\
\text { Rank }\end{array}$ & $\begin{array}{r}\text { Total } \\
\text { Ranks }\end{array}$ & $P$ \\
\hline 1 week & 5 & 0 & 0 & 0 & 0 & 0 & 7.5 & 37.5 & \\
2 weeks & 5 & 0 & 0 & 1 & 1.5 & 2 & 15.4 & 77.0 & \\
4 weeks & 5 & 0 & 0 & 1 & 1 & 1 & 14.4 & 72.0 & $0.01^{*}$ \\
12 week & 4 & 1 & 1 & 1 & 1 & 1 & 19.0 & 76.0 & \\
Control & 5 & 0 & 0 & 0 & 0 & 0 & 7.5 & 37.5 & \\
\hline
\end{tabular}

Min, minimum; Max, maximum; Q1, quartile 1; Q2, quartile 2. *Statistically significant according to Kruskal-Wallis $(P<0.05)$

\section{Two-minute experimental group}

In the first week of evaluation, the medullary tissue was altered, with deposition of dense fibrous connective tissue, large adipocytes, dispersed inflammatory infiltrate, vascular and intercellular edema, congested vessels and irregular areas of bone formation. This was characterized by bone matrix composed of large nuclei with osteocytes, differentiated and newly trapped osteoblasts, pervaded by paving with these osteoblastic cells arranged side by side. The histological degree of inflammation to this group obtained a mean score of one (mild), ranging from 0 (absent or scarce) and two (moderate). In the second week, the medullar component had been modified, displaying histological 
Costa FWG etal.

important inflammatory infiltrate dispersed through a fibrous areas of fat deposition and several congested blood vessels, besides locals of showing new bone arranged in trabeculae (Figure 4). In most animals of this group, there was this remarkable formation of immature bone beams, arranged between the fibro-fatty tissues produced. The histological degree of inflammation to the medullar tissue obtained an average score of two (moderate) with no change in severity.

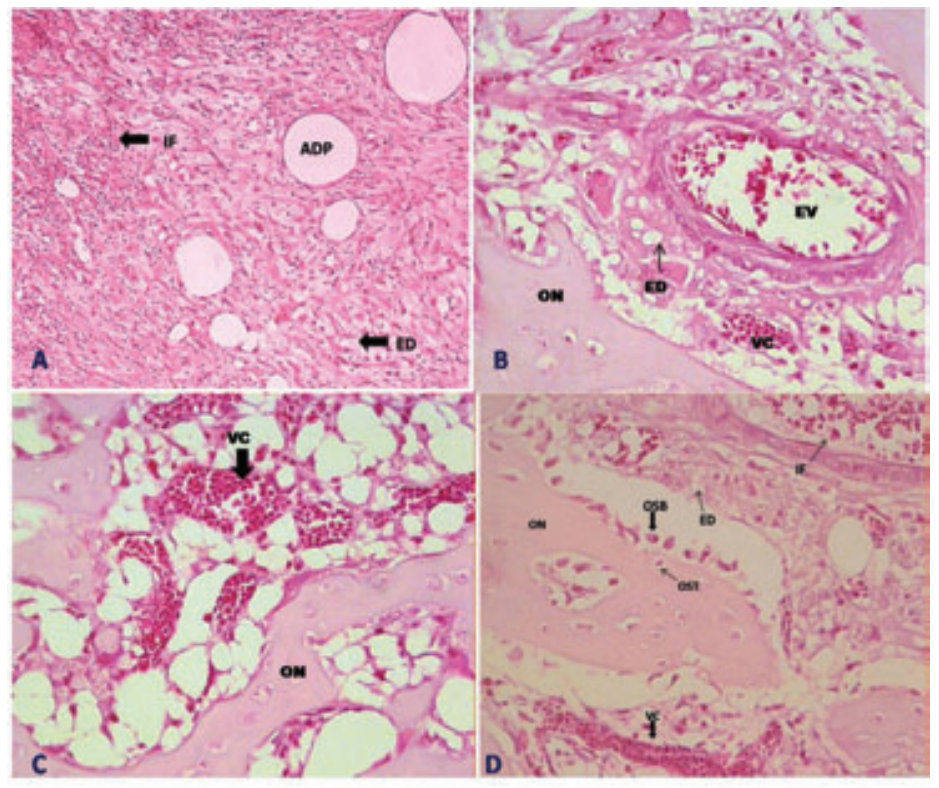

FIGURE 4 - Photomicrography of medullary tissue in protocol 2 minute / 2 weeks. A) Dense fibrous tissue with spindle cell / ovoid, inflammatory infiltrate (IF) dispersed, and adipocyte cell (ADP) bulky (HE, x100); B) Vascular edema (VE) and intercellular edema (DE), and congested vessels (CV), inflammatory cells and new bone (NB) (HE, x200); C) Irregular new bone formation, congested vessels by erythrocytes (HE, x200); D) Osteoid material characterized by osteocytes (OST) of large basophilic nuclei newly added to osteoblasts (OSB) at its periphery arranged in palisade, edema, inflammatory infiltrate and congested vessels (HE, $\mathrm{x} 100)$.

In the fourth experimental week, areas of bone formation in medullar tissue showed to have a greater degree of mineralization, with more compact extracellular matrix and differentiated osteocytes, fusiform and rejected nuclei, and the absence of osteoblastic paving. There were also a higher number of multinucleated giant cells permeating the bone tissue, and extravasated red blood cells, adipocytes and scattered inflammatory cells. The histological degree of inflammation to this group obtained a mean score of 0.5 (from absent or scarce and mild), ranging from 0 (absent or scarce) and two (moderate).

In the twelfth week, the medullar tissue was also changed, with most of the analyzed area consists of loose connective tissue associated with the presence of many fat cells. In addition, extravasated red blood cells, congested blood vessels and mineralized bone were found (Figure 5). The histological degree of inflammation to this group obtained a mean score of 1.5 (mild to moderate), ranging from one (mild) and two (moderate). Table 2 shows the degree of medullar histological inflammation in the two-minute protocol. The protocols were compared according to experimental weeks (Tables 3, 4 and 5).

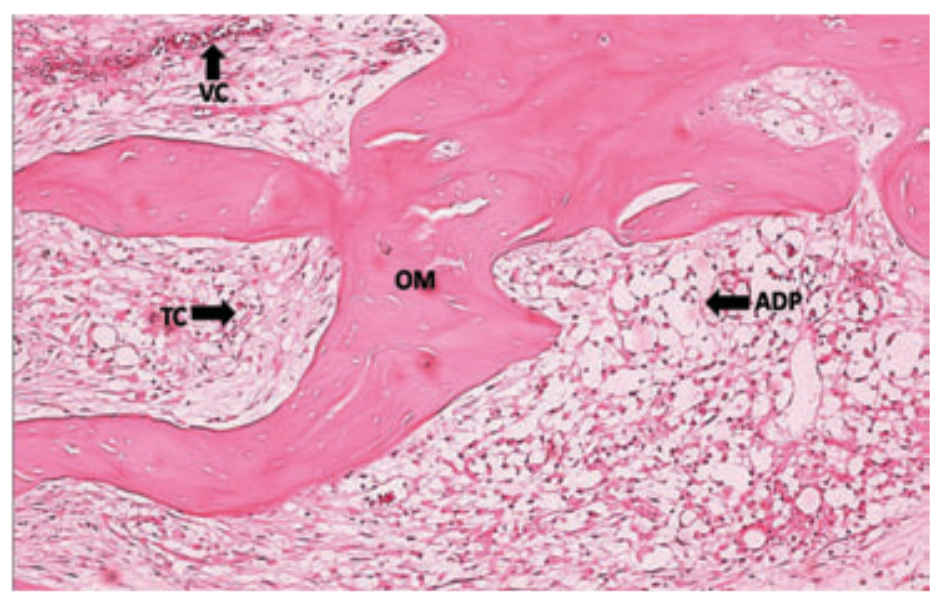

FIGURE 5 - Photomicrography of medullary tissue in protocol 2 minute / 12 weeks (HE, x100). Formation of mature bone tissue (MB) brought by connective tissue $(\mathbf{C T})$ loosely organized, with numerous adipocytes (ADP) and congested vessels (CV).

TABLE 2 - Degree of medullar histological inflammation between the 2-minute protocol.

\begin{tabular}{cccccccccc}
\hline Week & N & Min. & Q1 & Mean & Q3 & Max. & $\begin{array}{c}\text { Mean } \\
\text { Rank }\end{array}$ & $\begin{array}{c}\text { Total } \\
\text { Ranks }\end{array}$ & $P$ \\
\hline 1 week & 5 & 0 & 0 & 0 & 2 & 2 & 10.3 & 51.5 & \\
2 weeks & 5 & 1 & 1.5 & 2 & 2 & 2 & 17.5 & 87.5 & \\
4 weeks & 4 & 1 & 1 & 1 & 1.75 & 2 & 13.4 & 53.5 & $0.02 *$ \\
12 week & 4 & 1 & 1 & 1.5 & 2 & 2 & 15.3 & 61.0 & \\
Control & 5 & 0 & 0 & 0 & 0 & 0 & 4.5 & 22.5 & \\
\hline
\end{tabular}

Min, minimum; Max, maximum; Q1, quartile 1; Q2, quartile 2. *Statistically significant according to Kruskal-Wallis $(P<0.05)$

TABLE 3 - Degree of medullar histological inflammation between the protocols in the experimental $2^{\text {nd }}$ week.

\begin{tabular}{cccccccccc}
\hline Group & N & Min. & Q1 & Mean & Q3 & Max. & $\begin{array}{c}\text { Mean } \\
\text { Rank }\end{array}$ & $\begin{array}{c}\text { Total } \\
\text { Ranks }\end{array}$ & $P$ \\
\hline 1 minute & 5 & 0 & 0 & 1 & 2 & 2 & 7.8 & 39 & \\
2 minute & 5 & 1 & 2 & 2 & 2 & 2 & 12.2 & 61 & $0.01^{*}$ \\
Control & 5 & 0 & 0 & 0 & 0 & 0 & 4 & 20 & \\
\hline
\end{tabular}

Min, minimum; Max, maximum; Q1, quartile 1; Q2, quartile 2. *Statistically significant according to Kruskal-Wallis $(P<0.05)$ 
TABLE 4 - Degree of medullar histological inflammation between the protocols in the experimental $4^{\text {th }}$ week.

\begin{tabular}{cccccccccc}
\hline Group & N & Min. & Q1 & Mean & Q3 & Max. & $\begin{array}{c}\text { Mean } \\
\text { Rank }\end{array}$ & $\begin{array}{c}\text { Total } \\
\text { Ranks }\end{array}$ & $\boldsymbol{P}$ \\
\hline 1 minute & 5 & 0 & 0 & 1 & 1 & 1 & 7.9 & 39.5 & \\
2 minute & 4 & 1 & 1 & 1 & 2 & 2 & 11.4 & 45.5 & $0.01 *$ \\
Control & 5 & 0 & 0 & 0 & 0 & 0 & 4 & 20 & \\
\hline
\end{tabular}

Min, minimum; Max, maximum; Q1, quartile 1; Q2, quartile 2. *Statistically significant according to Kruskal-Wallis $(P<0.05)$

TABLE 5 - Degree of medullar histological inflammation between the protocols in the experimental $12^{\text {th }}$ week.

\begin{tabular}{cccccccccc}
\hline Group & N & Min. & Q1 & Mean & Q3 & Max. & $\begin{array}{r}\text { Mean } \\
\text { Rank }\end{array}$ & $\begin{array}{c}\text { Total } \\
\text { Ranks }\end{array}$ & $P$ \\
\hline 1 minute & 4 & 1 & 1 & 1 & 1 & 1 & 8.5 & 34 & \\
2 minute & 4 & 1 & 1 & 2 & 2 & 2 & 10.5 & 42 & $<0.01^{*}$ \\
Control & 5 & 0 & 0 & 0 & 0 & 0 & 3 & 15 & \\
\hline
\end{tabular}

Min, minimum; Max, maximum; Q1, quartile 1; Q2, quartile 2. *Statistically significant according to Kruskal-Wallis $(P<0.05)$

\section{Discussion}

Experimental studies in rat jaws described the major morphological responses to liquid nitrogen, when applied to bone, dividing them into three main phases ${ }^{7}$ : necrotic, osteogenic and remodeling. The necrotic phase corresponded to the first step after criolesion, settling in a matter of days until about a week. In osteogenic phase, which became evident after several weeks of the application of the cryogen, the marrow spaces were repopulated from the periphery of the frozen area by fibrous connective tissue. The stage of remodeling, last seen, followed by several months.

Bone marrow consists of a brown complex formed by various cell types that will coexist and interact in a synergistic way, as much of the haematopoietic system's own bone marrow stroma. After birth, it began production of blood cells at this site. The development of the bone marrow tissue occur in accordance with the colonization of blood precursors occupying the cavities of bone and cartilage, forming a close bond, and deep interdependence between these tissues ${ }^{8}$. Due to the presence of pluripotent mesenchymal cells inside, which will be available in medullary hematopoiesis, it can give rise to several other strains with different functions tissue formation according to the stimulus that has been submitted. Thus, by applying liquid nitrogen on the bone tissue, we defined three scores to quantify the severity of inflammatory process. Thus, we established that a score of 0 represents the absence or scarcity (up to $5 \%$ ) of inflammation, represent a mild inflammation score (above 5\% but less than $25 \%$ ), the score was represented as two (moderate) (above $25 \%$ and less than $75 \%$ ), and score three (intense or severe degree) (above $75 \%$ ).

In relation to one-minute protocol, there was a comparative study between the different weeks of sacrifice, has not been observed significant differences between groups, as well as between them and the control group (Table 1). However, when doing the comparison between the groups in two-minutes protocol, including the control, it was observed that although the Kruksal-Wallis test has accused significant difference, in fact, only real difference was found between the group B (two, four and 12 weeks) and control, when using the post-hoc Dunn's test (Table 2).

On the first week of the necrotic phase, we agree with the study by Emmings et al. ${ }^{9}$, that in addition to demonstrating complete necrosis of cortical bone in the first seven days, they found minimal infiltration of inflammatory cells and area of new bone formation in marrow cavity, as observed in our protocol of two minutes. However, the exuberant bone necrosis reported by these authors was probably due to the fact that they have adopted, also an application protocol with 15 minutes duration for each application.

Analyzing the second week trial, we observed inflammatory infiltrate ranging from mild (one-minute protocol) to moderate (two-minutes protocol), with areas of new bone deposition, when the established protocol of two minutes. This phase was markedly found in osteogenic phase of mandibular bone marrow tissue of rabbits studied by mandibular Kuylenstierna et $a l .{ }^{10,11}$.

Four weeks after surgery, we found the deposition of osteoid material, and mild inflammatory infiltration (protocol of one minute) to moderate (protocol of two minutes) in the marrow cavity. This finding was consistent coma research by Keijser et $a l{ }^{12}$ who analyzed the long bones of rabbits.

Interestingly, the marrow cavity, in the two-minutes protocol, showed a consistent pattern of fibro-adipose replacement, with the previously formed bone tissue is more compact and more differentiated osteocytes in the twelfth week trial, setting up a possible phase of bone remodeling. That finding was supported by Kuylenstierna et al. ${ }^{10,11}$.

In this study we observed no pathological fracture, even in the group two weeks of both protocols, where was observed the peaks of medullar inflammation, and corroborated by other studies such as those made by Kuylenstierna et al. ${ }^{10,11}$ and Popken et al. ${ }^{13}$. 


\section{Conclusion}

The degree of inflammation of the bone marrow tissue was higher in protocol of three applications of two minutes compared to protocol of three applications of one minute.

\section{References}

1. Costa FWG, Batista SHB, Soares ECS. Criocirurgia no tratamento de lesões benignas dos maxilares: revisão de literatura e análise de 103 casos previamente reportados. RSBO. 2010;7:208-15.

2. Schimidt BL, Pogrel MA. Neurosensory changes after liquid nitrogen cryotherapy. J Oral Maxillofac Surg. 2004;62:1183-7.

3. Salmassy DA, Pogrel MA. Liquid nitrogen cryosurgery and immediate bone grafting in the management of aggressive primary jaw lesions. J Oral Maxillofac Surg. 1995;53:784-90.

4. Pogrel MA. The use of liquid nitrogen cryotherapy in the management of locally aggressive bone lesions. J Oral Maxillofac Surg. 1993;51:269-73.

5. Farah CS, Savage NW. Cryotherapy for treatment of oral lesions. Aust Dent J. 2006;51:2-5.

6. Gurgel Costa FW, Castro Brito GA, Andrade Pessoa RM, Studart Soares EC. Effect of different cryosurgical protocols using liquid nitrogen on bone tissue: a histomorphological analyze. J Clin Exp Dent. 2011;3:e91-6.

7. Bradley PF, Fisher AD. The cryosurgery of bone: an experimental and clinical assessment. Br J Oral Surg. 1975;13:111-27.

8. Taichman RS, Emerson SE. The role of osteoblasts in the hematopoietic microenvironment. Stem Cells. 1998;16:7-15.

9. Emmings FG, Neiders ME, Greene GW, Koepf SW, Gage AA. Freezing the mandible without excision. J Oral Surg. 1966;24:14555 .

10. Kuylenstierna R, Anniko M, Lundquist PG, Nathanson A. Experimental cryosurgery on bone: a light and electron microscopical investigation. Cryobiology. 1980;17(6):563-70.

11. Kuylenstierna R, Lundquist PG, Nathanson A. Destruction and regeneration of jawbone after cryogenic application: an experimental study. Ann Otol Rhinol Laryngol. 1980;89:582-9.

12. Keijser LC, Schreuder HW, Buma P, Weinans H, Veth RP. Cryosurgery in long bones: an experimental study of necrosis and revitalization in rabbits. Arch Orthop Trauma Surg. 1999;119:440-4.

13. Popken F, Land M, Erberich H, Bosse M, König DP, Eysel P. The use of a new miniature cryoprobe for ablation of bone tissue: in vivo assessment of the probe and application of the method to bone in a sheep model. BMC Surg. 2003;3:3.

\section{Correspondence:}

Fábio Wildson Gurgel Costa

Rua João Sorongo, 1016/205

60416-000 Fortaleza-CE Brasil

Tel.: (55 (85)8819-1364

fwildson@yahoo.com.br

Received: September 14, 2011

Review: November 16, 2011

Accepted: December 12, 2011

Conflict of interest: none

Financial source: none

${ }^{1}$ Research performed at Laboratory of Pharmacology of Inflammation and Cancer (LAFICA/UFC), Division of Pharmacology, Federal University of Ceara (UFC), Fortaleza-CE, Brazil. 